\title{
RECORDS OF SELECTIVE FISHING MORTALITY OF Myliobatis goodei ON THE SOUTHERN BRAZIL COAST BY BEACH SEINE
}

\author{
Gonzalo Velasco $^{{ }^{*}}$, María Cristina Oddone ${ }^{2}$ and Renato Pereira Lopes ${ }^{3}$ \\ ${ }^{1}$ Universidade Federal do Rio Grande - Programa de Pós-Graduação em Oceanografia Biológica \\ (POBox 474, 96201-900 Rio Grande, RS, Brasil) \\ ${ }^{2}$ Universidade Federal do Rio Grande - Instituto de Ciências Biológicas \\ (POBox 474, 96201-900 Rio Grande, RS, Brasil) \\ ${ }^{3}$ Universidade Federal do Rio Grande - Instituto de Oceanografia \\ (POBox 474, 96201-900Rio Grande, RS, Brasil) \\ *Corresponding author: gonzalo.velasco.c@ gmail.com
}

\begin{abstract}
Descriptors: Southern eagle ray, Bycatch, Beach seine, Conservation.
\end{abstract}
Descritores: Raia-amarela; Arrastão de praia; Conservação.

The beach seine is a traditional kind of fishing gear used around the globe (NÉDÉLEC; PRADO, 1990; HAHN et al., 2007). It is generally regarded as an artisanal fashion of extracting fishery resources. It is, however, expected to have some impact on fish stocks (CABRAL et al., 2005; VOOREN; KLIPPEL, 2005). Moreover, as coastal areas are among the main reproduction and/or nursery areas for many species of bony fishes, elasmobranchs and other organisms (VOOREN, 1997; LAYMAN, 2000; ODDONE et al., 2006; LIMA; VIEIRA, 2009), its impact could be much greater than the volume caught may suggest.

Cassino beach is an extensive sandy beach of $c a .200 \mathrm{~km}$ in length in the extreme south of Brazil (Fig. 1) and represents a considerable portion of the central stretch of the world's longest sandy beach which, extending from Torres $\left(29^{\circ} 1935^{\prime \prime} \mathrm{S}\right.$ -

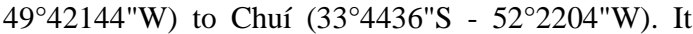
has a total, almost uninterrupted, extent of $620 \mathrm{~km}$ of straight sandy beach (CALLIARI, 1997; PEREIRA et al., 2010).

A total of 58 species of elasmobranchs inhabit the coastal waters, shelf and upper slope of Southern Brazil (VOOREN, 1997). The coastal area has been described as a reproduction and/or nursery area for several threatened species such as, for example, the Brazilian guitarfish Rhinobatos horkelii, the fanskate Sympterygia spp. and the scalloped hammerhead shark Sphyrna lewini (VOOREN, 1997; VOOREN et al., 2005).

Several kinds of fishing techniques, such as those of the traditional shelf fisheries with trawling gear, gillnets, long-lines, traps and purse seines, and the coastal gill-nets, beach seines and hook-and-line fisheries for teleosteans and elasmobranchs (HAIMOVICI et al., 1997; VELASCO et al., 2007), have been used in this region for decades. The use of the beach seine is a traditional activity for some local fishermen. This net is pulled up out of the water by 20 men or more, and the catch carried away by truck to the local markets or resellers (middlemen). Even though the decline of some of the coastal and surfzone species has been attributed to its use, this method of fishing is still used though its total yield is unknown to the environmental and fishery authorities (VOOREN; KLIPPEL, 2005).

The objective of this present contribution is to record a specific case of the impact of fishing by beach seine on an elasmobranch non-targeted species.

On November $5^{\text {th }}, 2010$, in the southern spring, during the whitemouth croaker Micropogonias furnieri (DESMAREST, 1923) fishery season, a large number of specimens of the Southern eagle ray Myliobatis goodei GARMAN, 1885 were found discarded and quantified during a visual beach survey trip, $48 \mathrm{~km}$ south of Cassino town, at $32^{\circ} 33^{\prime} 33.9^{\prime \prime} \mathrm{S}$ $52^{\circ} 23^{\prime} 56.9^{\prime \prime} \mathrm{W}$ (Fig. 1). Despite the fact that there is a taxonomic question regarding this species, with perhaps two Myliobatis species yet to be described (or even $M$. goodei re-described) according to Vooren (1997), these specimens were identified in accordance with the still valid descriptions of BIGELOW and SCHROEDER (1953) and FIGUEIREDO (1977). A total of 150 adult individuals were counted at a single location. These specimens were discarded within a restricted area of $\sim 100 \mathrm{~m}$ in length, probably as the result of a single beach seine trawl at that spot on the previous day (Fig. 2). Close-by, $5 \mathrm{~km}$ to the north, a beach seine trawl was being performed and along with a large amount of adult whitemouth croaker (unofficial information reported a yield of more than $1000 \mathrm{~kg}$ of this target-species), 15 individuals of Myliobatis goode $i$ were also captured and discarded, along with a 
handful of some teleostean fish (the Argentine menhaden Brevoortia pectinata (JENYNS, 1842), the largehead hairtail Trichiurus lepturus LINNAEUS,
1758, and the American harvestfish Peprilus paru (LINNAEUS, 1758), and a green turtle Chelonia mydas (LINNAEUS, 1758) that was released alive.

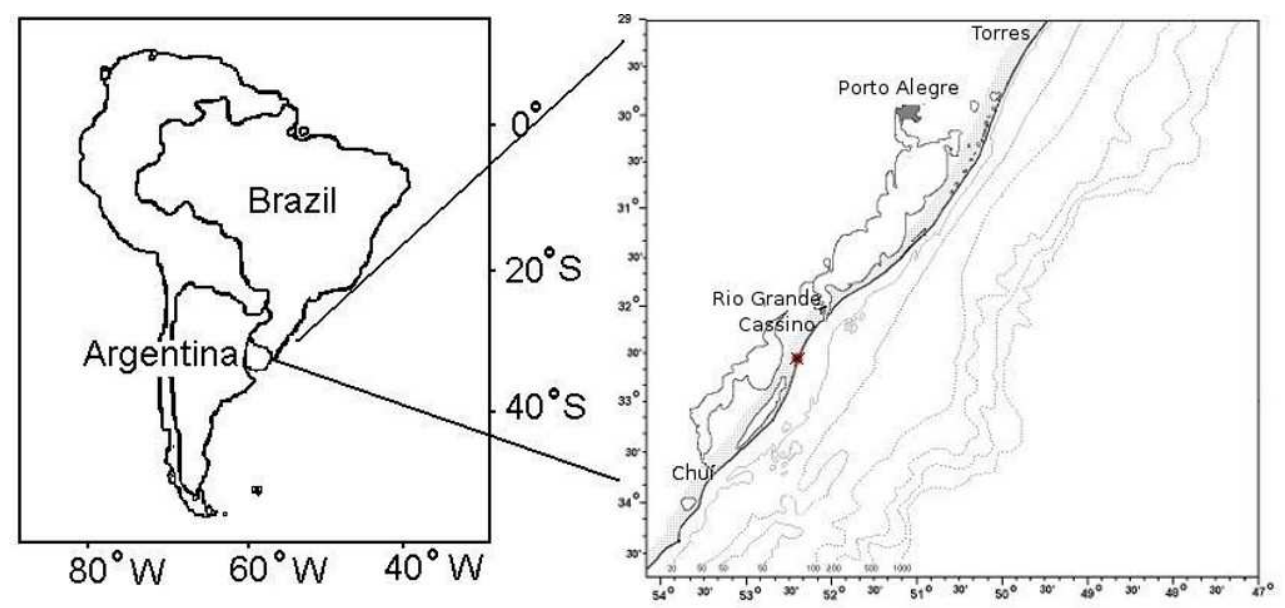

Fig. 1. Map of Rio Grande do Sul's coast, showing the collecting site (red spot at 32³3’33.9"S $52^{\circ} 23^{\prime} 56.9^{\prime \prime} \mathrm{W}$ ) where 150 individuals of Myliobatis goode $i$ were found discarded dead on November $5^{\text {th }}, 2010$.

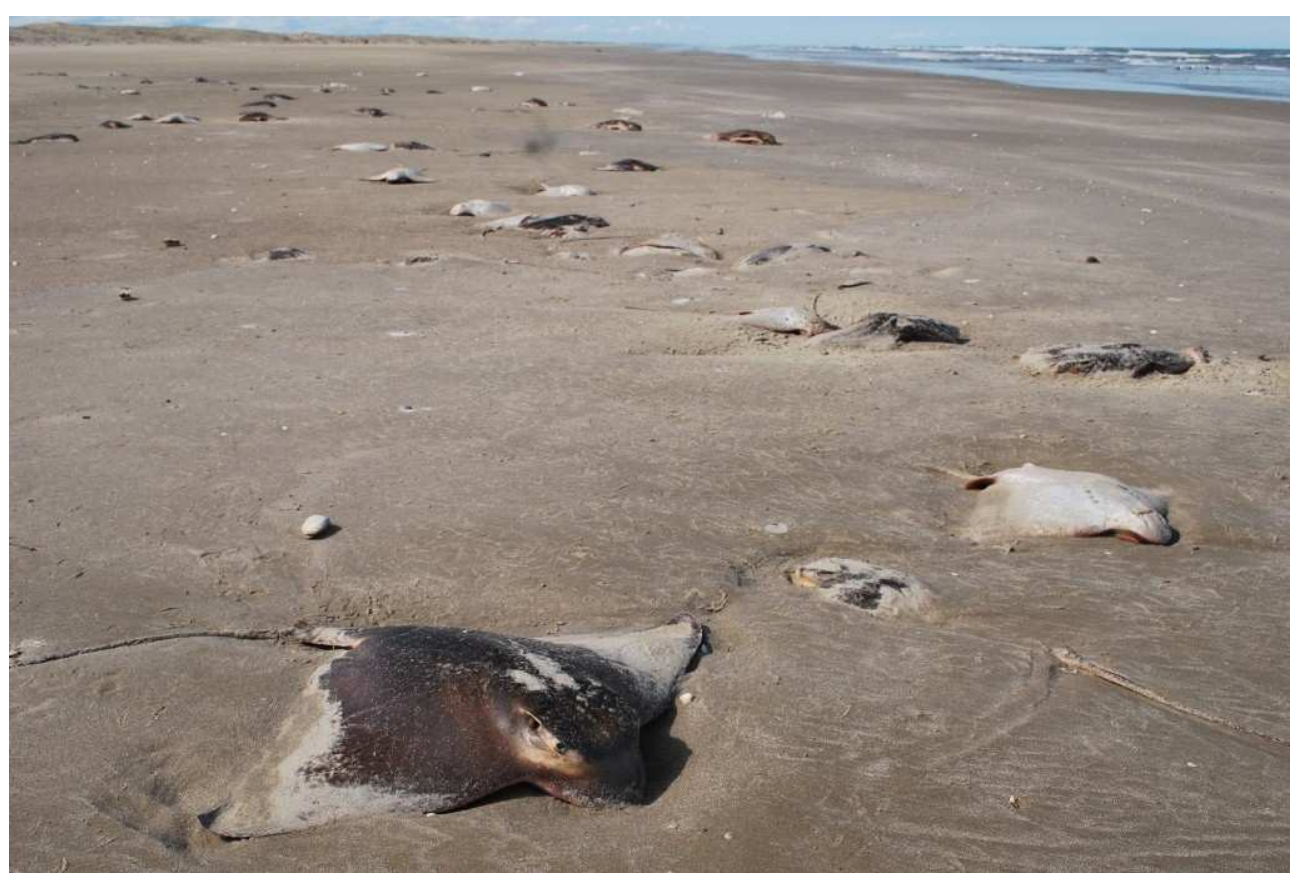

Fig. 2. Individuals of Myliobatis goodei $(\mathrm{N}=150)$ found discarded dead on November $5^{\text {th }}, 2010$ on Cassino beach, Southern Brazil. 
The Southern eagle ray Myliobatis goodei is widely distributed along the western coast of the Atlantic, from the United States $\left(36^{\circ} \mathrm{N}\right.$, South Carolina) to Argentina $\left(36^{\circ} \mathrm{S}\right.$, Patagonian region) (BIGELOW; SCHROEDER, 1953; FIGUEIREDO, 1977; COUSSEAU et al., 2007), and is considered as "Data Deficient" by the IUCN Red List of Endangered Species (see http://www.iucnredlist.org/apps/redlist/details/161436/0). Hence, reports of fishing mortality are important to feed future assessments, since by-catches are hardly ever recorded and are not therefore included in most assessments. It is unknown how often these catches occur in such an extensive area as the sandy beaches of Rio Grande do Sul State. Vooren and Klippel (2005) listed Myliobatis spp. among the species caught, but recorded smaller figures. However, if large catches like the first here recorded happen frequently, affecting the reproductive stock of a species of such low fecundity (VOOREN et al., 2005; GOMES et al., 2010), they must surely be an important source of mortality that calls for monitoring and should be taken into account in future species stock assessments.

CAPAPÉ et al. (2007) noted that the congeneric species $M$. aquila is mostly captured between August and October (in the northern summer) off the coast of Languedoc (southern France, northern Mediterranean Sea). This is due to the fact that pregnant females approach inshore waters for parturition. These specimens are commonly discarded on the beach in that region by fishermen soon after capture (CAPAPÉ et al., 2008). The large captures of $M$. goode $i$ in the area in question may be related to the seasonal movements of the females towards shallow waters for reproduction. Vooren (1997) observed that complex migrations of Myliobatis spp. took place in Southern Brazil during autumn and spring, although he made no reference to reproductive migration. It is, therefore, a matter of concern that the details of the reproductive cycle of this species be established in order to guarantee adequate conservation actions.

\section{ACKNOWLEDGMENTS}

The authors are grateful to their colleagues Getulio Rincon, Fabio L. Rodrigues, Valéria M. Lemos, Sérgio C. Estima, Monica B. Peres and Renata Montalverne for providing important references and/or information.

\section{REFERENCES}

BIGELOW, H. B.; SCHROEDER, W. C. Sawfishes, guitarfishes, skates and rays. In: TEE-VAN, J.; BREDER, C. M.; PARR, A. E.; SCHROEDER, W. C.; SCHULTZ, L. P. (Ed). Fishes of the Western North Atlantic. New Haven: Sears Foundation for Marine Research, 1953. Part 2, p. 1-514.
CABRAL, H.; DUQUE, J.; COSTA, M. J. Discards of the beach seine fishery in the central coast of Portugal. Fish. Res., v. 63, p. 63-71, 2003.

CALLIARI, L. J. Geomorphological settings. In: SEELIGER, U.; ODEBRECHT, C.; CASTELlO, J. P. (Ed.), Subtropical convergence environments: the coast and sea in the Southwestern Atlantic. Berlin: Springer, 1997. p. 91-94.

CAPAPÉ， C., GUÉLORGET, O., VERGNE, Y, QUIGNARD, J. P. Reproductive biology of the common Eagle Ray Myliobatis aquila (Chondrichthyes: Myliobat I D A E ) from the Coast of Languedoc (Southern France, Northern Mediterranean). Vie milieu: Life Environment, v. 57, n.3, p. 1-6, 2007.

CAPAPÉ, C., VERGNE, Y, QUIGNARD, J. P. New biological data on the Eagle Ray Myliobatis aquila (Chondrichthyes: Myliobatidae), off the Languedocian Coast (Southern France, Northern Mediterranean). Ann. Ser. Hist. Nat., v. 18, n.2, p. 167-172, 2008.

COUSSEAU, M. B.; FIGUEROA, D. E.; DÍAZ DE ASTARLOA, J. M.; MABRAGAÑA, E.; LUCIFORA, L.O. Rayas, chuchos y otros batoideos del atlántico sudoccidental: $34^{\circ} \mathrm{S}-55^{\circ} \mathrm{S}$. Mar del Plata: INIDEP, 2007. $102 \mathrm{p}$.

FIGUEIREDO, J. L. Cações, raias e quimeras. In: Manual de peixes marinhos do Sudeste do Brasil. São Paulo: Museu de Zoologia da Universidade de São Paulo, 1977.

GOMES, U. L.; SIGNORINI, C. N.; GADIG, O. B. F.; SANTOS, H. R. S. Guia para identificação de tubarões e raias do Rio de Janeiro. Rio de Janeiro: Technical Books, 2010. 234p.

HAHN, P. K. J.; BAILEY, R. R.; RITCHIE, A. Beach seining. In: JOHNSON, D. H.; SHRIER, B, M.; O'NEAL, J. S.; KNUTZEN,J. A.; AUGEROT, X.; O'NEIL, T. A.; PEARSONS, T. N. Salmonid field protocols handbook: techniques for assessing status and trends in Salmon and Trout populations. Bethesda, Maryland: American Fisheries Society in Association with State of the Salmon, 2007. p. 267-324.

HAIMOVICI, M.; CASTELLO, J. P.; VOOREN, C. M. Fisheries. In: SEELIGER, U., ODEBRECHT, C.; CASTELlO, J. P. (Ed.). Subtropical convergence environments: the coast and sea in the Southwestern Atlantic. Berlin: Springer, 1997. p. 183-196.

LAYMAN, C. A. Fish assemblage structure of the Shallow Ocean Surf-Zone on the Eastern Shore of Virginia Barrier Islands. Estuar. Coast. Shelf Sci., v. 51, p. 201213, 2000.

LIMA, M. S. P.; VIEIRA, J. P. Variação espaço-temporal da ictiofauna da zona de arrebentação da Praia do Cassino, Rio Grande do Sul, Brasil. Zoologia, v. 26, n.3, p. 499510, 2009.

NÉDÉLEC, C; PRADO. J. Definition and classification of fishing gear categories. Rome: FAO, 1990. 92 p.( FAO Fisheries Technical Paper, $\mathrm{n}^{\circ}$ 222, Revision 1)

ODDONE, M. C.; MESA, A.; AMORIM, A. F. The egg capsule of Rioraja agassizi (Müller \& Henle, 1841) (Elasmobranchii, Rajidae), endemic to the SW Atlantic. Pan. J. Aquat. Sci., v. 1, n.2, p. 43-48, 2006.

PEREIRA, P. S.; CALlIARI, L. J.; BARLETTA, R. C. Heterogeneity and homogeneity of Southern Brazilian beaches: a morphodynamic and statistical approach. Continent. Shelf Res., v. 30, p. 270-280, 2010. 
VELASCO, G.; ARAÚJO, J. N.; CASTELLO, J. P.; ODDONE, M. C. Exploring MSY strategies for elasmobranch fishes in an ecosystem perspective. Pan. J. Aquat. Sci., v. 2, n.2, p. 63-178, 2007.

VOOREN, C. M. Demersal elasmobranchs. In: SEELIGER, U., ODEBRECHT, C.; CASTELlO, J. P. (Ed.). Subtropical convergence environment: the coast and the sea in the Southwestern Atlantic. Berlim: Springer, 1997. p. 41-146.

VOOREN, C. M.; KLIPPEL, S. Ações para a conservação de tubarões e raias no sul do Brasil. Porto Alegre: Igaré, 2005. 262p.
VOOREN, C. M., KLIPPEL, S.; GALINA, A. B. Os elasmobrânquios das águas costeiras da plataforma sul, In: VOOREN, C. M.; KLIPPEL, S. Ações para a conservação de tubarões e raias no sul do Brasil. Porto Alegre: Igaré, 2005. p. 113-127.

(Manuscript received 13 February 2011; revised 05 April 2011; accepted 29 May 2011) 